\title{
FALA CANTADA - POÉTICA E MELÓDICA NA MUSICOLOGIA DE MÁRIO DE ANDRADE
}

Maurício de Carvalho Teixeira ${ }^{1}$

Para entender o pensamento musical de Mário de Andrade podemos dividi-lo em dois momentos: um primeiro que diz respeito às transformações da música brasileira no período modernista e outro que veja as permanências na música e nos processos de composição no Brasil. Estes dois movimentos (de transformação ou de permanência) estão ligados de forma dialética e um não se reconhece sem o outro.

O modernismo musical no Brasil coincide com várias mudanças nas manifestações culturais, no modo de vida e na tecnologia, e seus projetos estéticos estão muitas vezes associados a esse aspecto. Um fato interessante para pensar a crítica cultural do período é surgimento da indústria do lazer, justamente porque ela teve um grande alcance social, conquistando até as classes mais pobres, gerando um grande debate em torno desse tema.

Nas classes mais abastadas as evoluções são mais bem-vindas e no campo da música as metamorfoses técnicas e estruturais vinham acontecendo já a algum tempo - podemos pegar como exemplo a forma sonata, amplamente aplicada no século XIX, forma musical que gerencia as tensões e resoluções do ouvinte de um modo bem mais imediato e ligeiro que seus antecessores; outro exemplo foi a criação de salas de concerto, o que também evidencia o caráter cada vez mais comercial e imediato das obras musicais. E mesmo a difusão do piano doméstico e a produção e o comércio de partituras para esse mesmo instrumento.

Talvez por isso mesmo no século XIX a antiga noção de decadência moral e cultural tenha sido levada tão a sério pelo folclorismo romântico, e somou-se no início do século XX à preocupação com a destruição das comunidades isoladas geograficamente ou culturalmente (isoladas pelo analfabetismo, por exemplo). Com o avanço da urbanização as manifestações culturais ficaram cada vez mais ocidentalizadas no mundo inteiro, essa preocupação é generalizada nos anos 20, está por exemplo em Malinowski:

Agora, numa época em que [...] um pessoal adequadamente treinado para a pesquisa científica está começando a empreender viagem às regiões selvagens e a estudar seus habitantes, estes estão desaparecendo ante nossos olhos (Argonautas..., 1978, p. 12).

Malinowski chama sua disciplina de "moderna etnologia", provavelmente para se diferenciar dos viajantes e folcloristas dos séculos passados. Mário de Andrade entende o modernismo da etnologia em relação ao passadismo do folclore, um pouco ele se distancia dos folcloristas por essa razão - um conhecido artigo de Mário de Andrade sobre a música popular, chamado O Romance do Veludo (Veludo era o nome de um palhaço célebre que viajava pelo interior), começa com a frase:

Não sou folclorista não. [reparar na hipérbole criada pelos dois não, e continua] Me parece mesmo que não sou nada, na questão dos limites individuais, nem poeta (Romance do Veludo, Música doce música).

Essa citação é bastante significativa do pensamento de Mário de Andrade e é uma frase curiosa porque foi retomada por ele com as mais diversas variações. Ela mostra seus auto-

\footnotetext{
1 Doutorando em Letras, USP.
} 
questionamentos e sua consciência das limitações de qualquer pesquisa em música naquele momento.

Por exemplo, um fator importante no final dos anos 20 foi a difusão do fonógrafo e da gravação elétrica - justamente por marcar superação da escrita como único registro permanente do fenômeno sonoro, seja cantado, falado ou puramente instrumental, ou mesmo uma intersecção entre todas essas formas. Apresentava-se uma capacidade infinita de registrar o som (ou mesmo o ruído) muito mais eficiente que qualquer forma da escrita fonética ou musical.

Villers de L'Isle Adam autor muito próximo de Mallarmé foi prenunciador do choque cultural que causariam as transformações decorrentes da tecnologia. O seu romance Eva Futura (história de uma mulher movida à eletricidade e que tem dois fonógrafos no lugar dos pulmões que recitam trechos de literatura e filosofia) traz num de seus capítulos o título "As Lamentações de Thomas Edison" (o próprio inventor do fonógrafo é um de seus personagens):

Como cheguei tarde à humanidade! Murmurava. Por que não fui um dos primeiros homens de nossa espécie!... Boa parte das grandes palavras estariam incrustadas hoje (...) textuais, enfim, nas folhas de meu cilindro (...) E essas palavras ficariam gravadas ali, com o tom, o timbre, a maneira de pronunciar e até os vícios de pronúncia de seus enunciadores (Eva Futura, Villers de L'Isle Adam, p. 57).

Outra preocupação que a indústria fonográfica criava era que a música produzida para os discos ou para os estúdios de gravação não era mais considerada tão autenticamente popular (ou cientificamente popular para usar um termo da época). Por isso mesmo, a análise da música popular urbana e comercial não era o principal objeto de Mário de Andrade (mesmo que ele tenha presenciado e desfrutado daquelas músicas como ouvinte de fonógrafo que era). A musicologia marioandradina projetava uma cooperação entre uma música rural (ingênua, pura, folclórica) e a música de concerto moderna (séria, educadora, formal). No entanto, essa ausência persistente da música urbana, principalmente à música comercial, não é absoluta, e tem uma explicação que pode ser sintetizada nesse trecho do Ensaio sobre a Música Brasileira:

Por tudo isso não deverá se desprezar a documentação urbana. Manifestações há, e muito características, de música popular brasileira, que são especificamente urbanas, como o Chôro e a Modinha. Será preciso apenas ao estudioso discernir no folclore urbano, o que é virtualmente urbano, o que é tradicionalmente nacional, o que é essencialmente popular, enfim, do que é popularesco, feito à feição do popular, ou influenciado pelas modas internacionais (Ensaio, 1972:167).

Até aqui os posicionamentos de Mário de Andrade pouco se diferencia da maioria dos cronistas da época: a idéia da influência estrangeira decorrente da urbanização que desvirtua os costumes antigos - esses seus julgamentos têm a mesma tônica, por exemplo, das crônicas de Lima Barreto contra o futebol e as danças norte-americanas. O que Mário de Andrade traz, e sempre o caracteriza, é a bandeira do projeto estético modernista - a valorização da pesquisa estética "nas fontes do povo" para a criação artística, sobretudo em relação à música que foi seu principal objeto de estudo. 
Mas existe uma outra dimensão no pensamento musical de Mário de Andrade que é seu estudo sobre (não as transformações mas) as permanências na música brasileira, ou mais especificamente, nos processos de composição na língua cantada no Brasil.

A própria idéia da língua cantada é surpreendente, uma vez que essa língua-cantada teria uma sintaxe própria, uma prosódia e poderia ter até sua gramática. Uma gramática moderno-modernista da música brasileira, assim como existem as gramáticas simplesmente lingüísticas do português ou do português no Brasil (os anos 20 e 30 também foi uma época de questionamento e revisão de gramáticas e ortografias).

Uma carta de Mário de Andrade a Manuel Bandeira escrita em 1926 é bastante significativa porque antecede de seus estudos sobre a música brasileira. Ela trata do que Mário de Andrade chamou de torneios melódicos.

Do mesmo modo que os livros escolares, os manuais de retórica, tratavam dos torneios sintáticos da língua, Mário de Andrade pensava em identificar os torneios melódicos brasileiros. Todos os processos de composição de uma música poderiam ser analisados, então, pela categoria melódica:

Você me perguntava duvidoso: 'Quanto a torneios melódicos nacionais, haverá mesmo isso?' Certo que há. Porém se principio discutindo isso não acabo mais tanto o assunto é grande. Porém repare numa coisa: as músicas francesa, italiana e alemã não têm nenhuma rítmica particular, nem harmonização nem orquestração nem nada. No entanto se distinguem. Por onde? Primeiro pelo caráter psicológico, que é a coisa mais importante e é justamente o ponto por onde se discute a brasilidade de muita coisa que a gente exclui levianamente do patrimônio nacional. E depois? Se distingue pelo torneio melódico. Você perguntará: quais os torneios de cada uma? Segundo que não sei. Porque nunca me apliquei a esse estudo e ninguém não o fez ainda. Disso a culpa não é minha e me dificulta muito o meu trabalho. Porém algumas tendências mais freqüentes ou mais peculiares da nossa melódica já consegui distinguir.

Mário de Andrade fala depois que gostaria de compor uma "música brasileira sem nenhum dado característico da gente". Ou seja, uma música brasileira sem-nenhum-caráter, assim como o Macunaima. E essa música foi composta, e foi praticamente a única canção feita por Mário de Andrade, que é a Viola Quebrada.

Essa sua abordagem indica, entre outras coisas, como ele se opunha aos estereótipos sobre a musicalidade brasileira, como por exemplo:

- o Brasil é muito musical (ele achava que todos os povos eram musicais).

- a música do Brasil é muito rítmica (como na citação acima ele não acha que a rítmica é a principal característica nem que a rítmica brasileira tenha tantos procedimentos próprios que não existam em outros países).

- a rítmica brasileira é muito sincopada (Mário de Andrade dissociava síncope de dança, ou dinamogenia, a síncope poderia ser extremamente marcial ou retórico-discursiva dependendo da composição).

A hipótese dos torneios melódicos nunca foi retomada nesses termos pela literatura musical de Mário de Andrade. Porém, num de seus últimos textos ele retoma essa mesma idéia sem, no entanto, nomeá-la:

Tanto no campo como na cidade florescem com enorme abundância canções e danças que apresentam todos os caracteres que a ciência exige para determinar a validade folclórica dessa manifestação. Essas melodias nascem e morrem com rapidez, 
é verdade, o povo não as conserva na memória. Mas, se o documento musical em si não é conservado, ele se cria dentro de certas normas de compor, de certos processos de cantar, reveste sempre formas determinadas, se manifesta sempre dentro de certas combinações instrumentais, contém certo número de constâncias melódicas, motivos rítmicos, tendências tonais, jeitos de cadenciar, que todos são já tradicionais, já perfeitamente anônimos e autóctones, às vezes peculiares, e sempre característicos do brasileiro. Não é tal canção determinada que é permanente, mas tudo aquilo de que ela é construída. A melodia, em seis ou dez anos, poderá obliterar-se na memória popular, mas os seus elementos constitutivos permanecem usuais no povo e com todos os requisitos, aparências e fraquezas do tradicional ("Folclore" In Manual de Estudos Brasileiros, 1949).

Durante toda sua vida, Mário de Andrade recolheu (anotou, analisou) canções e danças-cantadas sempre de forma bem descritiva. Mas olhando o conjunto da sua literatura musical percebemos seus instrumentos para a análise da música brasileira.

Primeiro está bem definindo seu objeto de estudo: a poesia cantada. Dentro desse objeto a abordagem é o estudo das relações melódico-poéticas. Portanto letra e música formam uma unidade que deve ser analisada em conjunto.

Para Mário de Andrade grande parte das características melódicas é justificada pelo texto poético que acompanha as canções e danças - e o contrário também ocorre: as palavras aparecem justificadas por razões apenas sonoras ou musicais. Nas relações poético-melódicas estão os motivos não-literários de um texto poético (é o que Leo Spizer aborda ao questionar o uso e análise das chamadas "palavras irracionais"). Existem palavras no poema que estão ligadas dinamicamente ao tempo da leitura, à métrica e, portanto ao ritmo - além de guardarem um aspecto imediatamente sonoro. Outras palavras levam uma melodia a ser crescente ou decrescente, ter intervalos maiores ou menores entre as notas da escala, ou mesmo (como acontece muitas vezes) fugir da sua própria escala.

Isto é claramente visível em toda sua literatura musical porque os versos populares analisados sempre vêm unidos a uma melodia (quase não há verso sem partitura ou partitura sem verso). Essa percepção de uma relação simultânea entre a função poética da música e da função musical do texto pode ser pertinente à análise das mais diversas músicas, como essas que se ouve no rádio, ou as óperas de Wagner, ou as cantatas de Bach.

A justificativa sonora para a composição do texto poético está no centro das transformações por que passaram a poesia desde a segunda metade do século XIX. A poesia melódica (sonora ou mesmo visual) defendida por Mallarmé, Verlaine, Valéry, etc. marcou uma divisão no mundo poético. A aceitação do aspecto mais imponderável menos lexical, levou também a uma recusa do preciosismo e outras afetações que demonstravam uma ausência de preocupação com o tempo de criação e o tempo de escuta do poema - ou seja, o tempo do ouvinte. Portanto, a justificativa final para a pesquisa musical de Mário de Andrade vem em grande parte de sua experiência poética. E vem de uma poética muito questionadora dos usos que se fez das poéticas clássicas nos manuais escolares do século XIX - isso é um traço crítico tanto dos modernistas brasileiros como dos simbolistas franceses.

Mário de Andrade começou seus estudos sobre a música no Brasil elegendo a análise melódica como a que mais provavelmente encontraria um caráter musical brasileiro. Mas a análise melódica não tem seus limites muito bem definidos como as suas correlatas, a análise rítmica, harmônica. 
Em melodia está contido o ritmo, a harmonia (o tom, os modos, os acidentes/dissonâncias). Estudos recentes apontam o que MA já indicava em seus escritos: que a relação música-texto deve ser pensada em todas as suas dimensões e de forma recíproca entre os dois elementos - a poeticidade das melodias e a musicalidade dos poemas. E a canção como manifestação lingüístico-musical simboliza em suas células essa unidade.

O aspecto poético da canção aparece como um estudo específico da forma, do estilo e da sonoridade, tanto quanto um estudo do conteúdo ou do assunto abordado. Esse viés poético acabou dando outra direção a todas as análises de Mário de Andrade, aproximando-os muito mais de um estudo de linguagem, mas que examina, sobretudo, a dimensão musical dessa linguagem. 